\title{
The Models of Islamic Syiar Approach by the Religious Counselors in Developing Religious Life in East Lampung Regency
}

\author{
Mubasit \\ UIN Raden Intan Lampung \\ mubasit@radenintan.ac.id \\ Fitri Yanti \\ UIN Raden Intan Lampung \\ fitriyanti@radenintan.ac.id
}

\begin{abstract}
Abstrak
Lampung Timur merupakan salah satu basis kaum muslim di Propinsi Lampung. Namun persoalan yang dihadapi kaum muslim di Lampung Timur juga cukup kompleks. Mulai persoalan demoralisasi, kriminalitas dan lain-lain. Penelitian ini bertujuan untuk mendeskripsikan dan menganalisis model pendekatan Islamic syiar yang dilakukan oleh penyuluh agama di Lampung Timur. Penelitian ini menggunakan metode kualitatif deskriptif. Pengumpulan data dilakukan dengan wawancara mendalam bersama para informan yang berkaitan langsung dengan kegiatan penyuluhan agama di Lampung Timur. Selain itu dilakukan juga pengamatan langsung (observasi) terhadap kegiatan Islamic syiar yang dilakukan oleh para penyuluh agama. Penelusuran dokumen dilakukan juga untuk mendapatkan data-data yang relevan terkait aturan, kebijakan dan ketentuan yang berhubungan dengan penyuluh agama. Dari penelitian yang dilakukan, penyuluh agama di Lampung Timur menggunakan tiga pendekatan dalam melakukan tugas Islamic syiar di tengah masyarakat. Pertama, pendekatan sosial budaya. Kedua, pendekatan psikologis. Ketiga, pendekatan politik.
\end{abstract}

Kata kunci; penyuluh agama, psikologi-politik, syiar Islam, sosial-budaya 


\begin{abstract}
East Lampung has been known as one of the Muslim bases in the Lampung Province. However, problems faced by Muslims in this region are quite complicated. Some of these issues are demoralization and the highly rate of criminalization. This study aims to describe and analyse the models of Islamic syiar approach applied by the religious counsellors in East Lampung. This research uses the descriptive qualitative method. The data is collected through in-depth interviews with the informants who have direct relation to the religious counselling activities. Besides, the direct observation is involved in analysing the activities of religious counsellors in doing their Islamic syiar. Moreover, surfing related documents to obtain relevant data with religious counselling activities such as rules, policies, and provisions is also entangled. Based on the conducted research, the religious counsellors in East Lampung use three approaches in performing their syiar in their community. They are the socio-cultural approach, the psychological approach and the political approach.
\end{abstract}

Keywords; Islamic syiar, psychology- politics, religious counsellors, socialculture.

\title{
Introduction
}

Current dawah activities tend to be dominantly carried out with the speech method (Fitria \& Aditia, 2019). This method is efficient to the emotional aspect of the cognitive and is less to the affective aspect (Hakim, 2017). The Oral syiar concerns more to the talk aspect displayed by the preacher (Kamaluddin, 2020). The success of this method is measured from the knowledge of the object of Islamic syiar. Delivering lectures or speeches in the form of the oral Islamic syiar is generally performed in podiums, pengajian, majelis taklim, etc. (Nurhayati et al., 2018). The Oral Islamic syiar touches commonly the issues of poverty, underdevelopment, etc. rather than the other issues(Wastiyah, 2020). In this digital age of the modern era, delivering Islamic syiar requires the preachers to comprehensively have multi-talents and skills in challenging the change of the era. (Budiantoro, 2018). Islamic syiar should touch well the essence of the subject of Islamic syiar. Moreover, it should give the good solution to the problems of life faced by audients. (Kholili, 2017). On the other hand, Participant 15 et. al. stated that the material objects of Islamic syiar should encourage the audients by giving them the religious spirit to work hardly, to develop entrepreneurship skill and to be honest in facing their life (Bahtiar et al., 2020).

One of the preachers who still exist in the heart of the community is the religious counselor. The religious counselor is the officer recruited by the Ministry of Religious affairs to give counseling and enlightenment to the Muslim community. (Muslihudin et al., 2017). As a preacher, the religious 
counselor in Indonesia is deal with various problems faced by the Muslim community. These issues are more diverse and complex following the change of the time. The complexity of these problems increases and overlaps by the time ranging from the question of people religious understanding, poverty to retardation, etc. (Mujahidin, 2008). from the small scales such as poverty and ignorance (Iskandar, 2018), to the large scales such as conflict and terrorism (Suriati, 2019). The religious counselors are required to continuously give advice and enlightenment to the Muslim community in increasing their religious knowledge, and making efforts in developing themselves, including expanding their economy and education. Therefore, they can move away from the the developmentally disabled condition and, subsequently, they are able to live independently, helpless and can empower other people at least in their own families and nearest neighborhoods(Isnanto, 2018).

The preachers of Islamic religion can succes in carrying out their duties in the community if they master some of the components of the selected and formulated Islamic syiar strategy, and then apply them to the heart of the Muslim community. (Kusnawan, 2017). The plurality of Muslim societies in Indonesia becomes a challenge for the religious counselors to perform their syiar activities to all elements of the Muslim community without giving discrimination to the different groups of religious understanding, religious tradition, religious culture, and spiritual practices (Busyro et al., 2019) due to Indonesia's Muslim population that are very plural or compound. Muslim communities in Indonesia have various backgrounds in term of their tribe, race, traditions, language, and socioeconomic status. (Ali \& Noor, 2019). This reality demands religious counselors to create a good strategy in performing their duties as well as to communicate well with the right target of Islamic syiar.

Religious counselors should deal with the relatively hard duties and responsibilities. In one side they are required to have spiritual comprehensive and holistic ability to understand and communicate with all circles of the Muslim society, which is plural (Rosidin et al., 2020), while in the other side they are also required to have expertise in driving the Muslim community to do activities and efforts that could bring them out from the trap of ignorance and retardation (Indriani, 2019). The religious counselors need good knowledge, skills and ability to motivate and set a good example of success to their audients. This is not easy, because as a preacher, they must become the prototype and role model of the Muslim community as their object of Islamic syiar (Dachlan, 2017). Beside their competency to communicate well with the 
Muslim community, religious counselors are also required to improve their performance through a program that can directly resolve the religious issues among communities that are increasingly complex (Ilham, 2018).

The religious counselors need to provide themselves as well by improving their ability and competence in doing Islamic syiar and religious activities (Surahmat, 2020). Having good communication skills and economic abilities that can make themselves financially independent are also the conditions that should be engaged by religious counselors (Bait, 2017). Furthermore, the most important thing is fostering their family as a happy and prosperous family. (Manu et al., 2020). After it is new on the stages of fostering of the Muslim community or people who live a full life of compassion to create the state of life the religious, side by side in harmony and peace (Jaya, 2017). In this stage, the development of Islamic syiar activities leads to form the value of work ethic among the ummah or Muslim community. Therefore, the Muslim community can live independently and do not depend on other parties and on government assistance. (Andrian, 2019). If these are achieved, the Islamic syiar of the religious counselors is deemed to be success in building the power of the Muslim community.

Empowering the Moslem community has become an essential task of religious counselors. The alms giving is one of empowerments to the object of Islamic syiar that can grant the helpless of them to have an ability (Ramdhani, 2018). Delivering Islamic syiar to defenseless people is undoubtedly assumed as not an easy work in just only one or two times of efforts, it needs an intensive and continuous hard work. (Masrial, 2018). The efforts are also intended to build a partnership with various stakeholders of the government beginning from the smallest level, in this case the local government administrates, to the highest level, namely the ministry administrates in the national level. In these situations, the good communication and performance are the two factors that determine the successful of the religious counselors in bringing out the Muslim community from ignorance, poverty, and underdevelopment (Munawar, 2017). The village funds which are mostly disbursed by the central government to villages should be one part of the program that can be synergized between the religious counselors and the village's administrates. (Zaini, 2107). At the level of the fostering aspects of the religious and the side of the mental development of the Muslim community in the village and the element of economic empowerment of the Muslim community in the town. 
The Islamic syiar communication has been already studied by scholars and researchers in Indonesia and outside. However, not all aspects of it are already captured in their research. This study will give an explanation of the wrong perspective of the new research and reviews related to syiar communication of religious counselors in Indonesia. Among the research that has been conducted by scholars are the research done by Julis Suriani. Suriani researched the importance of Islamic syiar communication through the internet in the digital age (Suriani, 2018). Participant 6 who investigated the Islamic syiar communication through the internet. He stated that the presence of the information technology such as the internet opens up new opportunities for preachers (religious counselors) to develop their syiar communication to be more quickly and to be wider range of audients (Rustandi, 2020). The research done by Usfiyatul on the Islamic syiar communication in the era of multiculturalism. According to her, the historical resources can be done anywhere and anytime, including in a multicultural society. Islamic syiar in a multicultural society with the culturally diverse approach should follow the conditions of the object of Islamic syiar (Marfu'ah, 2018). the research on the syiar communication in promoting the Islamic religion done by Nurul Laila Hidayat. Hidayat researched the strategies to proselytize the Islamic religion in fostering a sakinah family (Hidayat, 2020). Babay Barmawie and Fadhila Humaira researched the Islamic syiar communication of religious counselors in fostering religious tolerance (Barmawie \& Humaira, 2018). the research on the syiar communication in the era of pandemic covid-19 through social media such as Whatsapp by Sri Muchlis. Social Media is one of the effective means of Islamic syiar communication in the pandemic covid-19 time (Muchlis, 2020). This study discusses the syiar communication performed by religious counselors in East Lampung, Lampung Province. This article seeks to describe and analyze the communication performance of the religious counselors. This article aims to determine the communication process performed by the religious counselors in East Lampung. The study also seeks to explain the processes and the results of the Islamic syiar communication performanced by religious counselors.

\section{Literature Review}

According to Harold D Lasswell, communication is defined as the process of conveying the message carried out by the communicator or the person who gives the news, to the communicant or the object of 
communication, through the medium of / for a specific channel to get feedback or response. (Lasswell, 1979). The giver of the message has a specific purpose when it comes to communication. The goal is to be achieved at the time of communicating. (Abazari \& Borjian Brojeni, 2017). Communication can be verbal and non verbal (Sutiyatno, 2018). Communication has an extensive scope starting from a specific organization to the unlimited audients (Keyton, 2017). Good communication can be carried out as a means of effective learning, so that the learning atmosphere can take place in a fun (Kurniawan, 2018). On the specific scope, communication can be in the form of solicitation, motivation and appealing to do or not to do something (Ningrum, 2013). Communication is an important part which will not be avoided in the Islamic syiar activities. The da'is should deal with some of communication models to apply to the different targets of Islamic syiar.

Performance is a significant factor in every institution (Andayani \& Tirtayasa, 2019), because it is a factor that largely determines the success of the agency (Nurnaningsih \& Wahyono, 2017). Institutions that have good performance will deserve a good reputation and will also get the recognition from the outside (Wahyuningsih, 2018). On the contrary, if the performance is not good, the institution will not have a good reputation and will be difficult to gain recognition. As a result, it will have difficulties in establishing a cooperation with other institutions (Lawasi \& Triatmanto, 2017). In carrying out the tasks in a special period of work, the institutions involved in the same job and responsibility are required to gain achievements that can raise the name of the institution or company (Yulianingsih \& Sobandi, 2017). Performance is resulted from the implementation of work which is measured at a particular time (Rialmi \& Morsen, 2020). Performance can be individual or institutional, it depends on whether there is a cooperation with all elements of the institution or not (Amanda et al., 2016).

Performance is internally influenced by several factors, such as work discipline, work motivation, knowledge and skills, the internal environment of the institution, leadership, strategy, vision, mission, structure, system of formal and non-formal education and training and regulations of the institution. (Margaretha \& Letty, 2017). In addition to internal factors, external factors also affect the performance of an institution, such as the environment of the partner institution, the government, and the community (Fibriyani \& Mufidah, 2018). 
Communication and performance are two different things and each has separate concepts. However, both practically have a tied connection and relation. The communication strategy could have an impact on the performance of the company as it happened in one companies in the Regency of Sumenep, East Java (Hidayaturrahman, 2017). In private organizations, such as the company, communication is also associated with the employees' performance (As'ad, 2018). Good communication among fellow employees, employers and employees will improve the tension of understanding with no bulkhead or obstacles. (Afianto \& Utami, 2017). On the contrary, the hampered communication will make the information does not go smoothly and will cause stiffness and rigidity. Stiffness and rigidity in the organization will hinder the performance issues if there is a problem that cannot be solved (Fachrezi \& Khair, 2020).

Communication that is not running well tends to cause conflict and it can give a negative impact on overall performance of an institution (Yulianti, 2017). According to George Simmel, society is more than just a collection of individuals and behaviors. However, it depends on every individual that shapes it. On the contrary, the community refers to patterns of the interpersonal interaction reciprocity (Marta, Rizo García, 2006). Simmel stated that the form of social interaction is defined as a pattern of behavior which is universal and always stand on the meaning of the range of the contents disclosed. The contents of the social life include the instinct of the erotic, the interests of Objectif, religious encouragement, help or commands, etc. All of this entire contents can cause people to share life with others, to act against them, to cooperate with them, to influence and to be influenced, and even to fight against them (Mele, 2017).Simmel explained that one of his main interests is the interaction (association) of conscious interactors. The purpose of interest is to see the magnitude of the exchange scope when it may look trivial but in another moment is very important. From the standpoint of Simmel, the real world composed of events, actions, interactions, and so forth infinitely (Roessler \& Mokrosinska, 2013).

\section{Method}

This research uses the descriptive qualitative method. The study describes the religious counselors' communication based on performance and human resource management in East Lampung, Lampung province,. The Data was collected through in-depth interviews with the informants who are 
directly involved in the syiar activities done by religious counselors. The interviewed informants were selected from different backgrounds in order to get the information more widely. Furthermore, the data collected from the informants were re-checked to get a valid data and it is a part of the process of the source triangulation conducted by the researchers. The informants were chosen based on the selection that has been determined (purposive sampling). The choice of informants was based on the level of their representativeness.

Table 1. Informants who were Interviewed (Source: Researchers, 2020).

\begin{tabular}{|c|c|c|c|}
\hline Num & Names & The Task & $\begin{array}{l}\text { The Location of the Task } \\
\text { the Informant }\end{array}$ \\
\hline 1 & Participant 1 & $\begin{array}{l}\text { Religious counselors } \\
\text { Religious counselors }\end{array}$ & $\begin{array}{l}\text { The Office of Religious Affairs } \\
\text { Batanghari }\end{array}$ \\
\hline 2 & Participant 2 & Religious counselors & $\begin{array}{l}\text { The Office of Religious Affairs } \\
\text { Pekalongan }\end{array}$ \\
\hline 3 & Participant 3 & $\begin{array}{l}\text { Religious counselors } \\
\text { Religious counselors }\end{array}$ & $\begin{array}{l}\text { The Office of Religious Affairs } \\
\text { Batanghari Nuban }\end{array}$ \\
\hline 4 & Participant 4 & Religious counselors & $\begin{array}{l}\text { The Office of Religious Affairs } \\
\text { Purbolinggo }\end{array}$ \\
\hline 5 & Participant 5 & $\begin{array}{l}\text { Religious counselors } \\
\text { (Coordinator of the } \\
\text { Working Group Religious } \\
\text { counselors) }\end{array}$ & $\begin{array}{l}\text { The Office of Religious Affairs } \\
\text { Way Jepara }\end{array}$ \\
\hline 6 & Participant 6 & $\begin{array}{l}\text { Religious counselors } \\
\text { Religious counselors }\end{array}$ & $\begin{array}{l}\text { The Office of Religious Affairs } \\
\text { Metro Kibang }\end{array}$ \\
\hline 7 & Participant 7 & Religious counselors & $\begin{array}{l}\text { The Office of Religious Affairs } \\
\text { Sekampung }\end{array}$ \\
\hline 8 & Participant 8 & $\begin{array}{l}\text { Head of Section the } \\
\text { Guidance of Islam }\end{array}$ & $\begin{array}{l}\text { The Office of Religious Affairs } \\
\text { Lampung Timur }\end{array}$ \\
\hline 9 & Participant 9 & Employees & $\begin{array}{l}\text { The Office of Religious Affairs } \\
\text { Regency of East Lampung }\end{array}$ \\
\hline 10 & Participant 10 & Religious figures & District of Pekalongan \\
\hline 11 & Participant 11 & Religious figures & District of Way Jepara \\
\hline 12 & Participant 12 & $\begin{array}{l}\text { Head Office Religious } \\
\text { Affairs }\end{array}$ & District of Batanghari \\
\hline 13 & Participant 13 & $\begin{array}{l}\text { Head of the Division of } \\
\text { Administration }\end{array}$ & $\begin{array}{l}\text { The Office of Religious Affairs } \\
\text { of East Lampung }\end{array}$ \\
\hline 14 & Participant 14 & $\begin{array}{l}\text { The Head of the Ministry } \\
\text { of Religious Affairs }\end{array}$ & Regency of East Lampung \\
\hline 15 & Participant 15 & $\begin{array}{l}\text { Secretary of the } \\
\text { Group religious } \\
\text { counselors }\end{array}$ & Regency of East Lampung \\
\hline
\end{tabular}

The Data was also collected by observing the process of communication of Islamic syiar carried out by the Islamic religious counselors in East Lampung Regency during the period year of 2019-2020. The results of the observation 
obtained by the researchers are, then, documented in the form of photographs, some of which are attached in this articles. In addition, the observation done by the researchers also as a part of efforts to cross-check the information given by the informants at the time of in-depth interviews. The researcher also searched related documents and references to the study which are obtained from peerreviewed journals nationally and internationally. Therefore, the results of the survey are rich of data and in a form of in-depth discussion.

The Technical data analysis conducted by the researchers referred to the technical data analysis proposed by Miles and Huberman (Miles; \& Huberman, 1994). According to Miles and Huberman, the technical data analysis includes data reduction. At this stage, the data has been successfully collected. The data collected from the field was, then, selected and sorted for the following purposes. Not all data obtained in the field research were relevant to the research topics. The data that have been chosen and selected were, then, presented in a narrative form following the research topic. Finally, new conclusions drawn on the results of the research were discussed.

\section{Role of Counselor's in Developing Religious Awarness}

The Religious counselors in East Lampung Regency are consisting of state civil servants (ASN) and non-ASN (voluntary employees). Each religious counselor has to nurture two villages in one sub-district. They are demanded to deliver speech in front of the majelis taklims, which have been scheduled regularly. They must hold at least eight activities every month and should report them as a proof of their performances and the report has to be signed and acknowledged by the head of the local Religious Affairs Office (KUA).

They are subsequently submitted that report to the Head of the Islamic Community Guidance Section to the Ministry of Religious Affair in local Regency office. ASN religious counselors must be religious scholars and, meanwhile, those are non-ASN who did not hold a religious education degree must obtain a recommendation from the Indonesian Ulema Council (MUI) at district level. Moreover, they must be form a social organization and should have two majelis taklims to nurture. They must also be required to be proficient in reading the Quran, be able to read Arabic books, have extensive knowledge, and be a good healthy physically and mentally (The interview with Participant 8 , the Head of the Islamic Community Guidance Section of the Ministry of Religion, East Lampung office, February 5, 2020). 
East Lampung regency has 24 districts, 264 villages, and the number of majelis taklim that have been counted is 376 both towns and villages. To fill out the lack of religious counselors in East Lampung Regency, the local government employs 192 non-state civil servants (ASN) religious counselors. So that, it is almost every day, the religious counselors hold the majelis taklim all over the regency. The other things that they carry out in majelis taklim in their syiar activities are youth coaching, drug counseling, marriage guidance, spiritual guidance for patients in hospitals, etc. (the interview with Participant 5, Functional Religion Officer of Way Jepara District and Coordinator of the East Lampung Regency Religious counselors assemble, January 7, 2020).

East Lampung Regency is one of the largest Muslim bases in Lampung Province. Therefore, the task of religious counselors in this regency is not an easy job. The job needs an organized strategy and focus. The process of providing religious guidance and counseling requires hard work. Besides, religious counselors are challenged with global realities, which have caused a decrease in the number of Moslems who understand, appreciate, and practice Islamic religion well. This is due to the strong global negative values that influence Muslims behaviors. Globalization, in some extends, fosters an orientation, attitude, and lifestyle that ignore religious values. These, then, will lead to demoralization in people's lives.

The advancement of the latest information technology devices is argued as one of the rising of this moral and ethical vulnerability. The global negative values can be accessed easily through the development of internet, some of these values are gambling, drugs, criminalization, pornography, porno-action, etc. The other problems that are faced by religious counselors are over population, environmental damage, global warming, health, poverty, demoralization, and ignorance. The religious counselors need a good strategy to overcome these issues by giving the people religious enlightenment and solution (the interview with Participant 7, functional religion counselor in Sekampung District, January 7, 2020).

\section{Islamic Syiar Approach Models of Religious Counselors}

As part of their task, religious counselors need to have a good strategy and approach in carrying out their syiar activities. These strategies and approaches should be applied and situated with the conditions of the target of 
Islamic syiar. The religious counselors must have some approach models in carrying out their syiar that can be implemented simultaneously and continuously. As an addition, the Islamic syiar approach carried out by religious counselors can also adopt what had been done by the Prophet Muhammad SAW which he started the Islamic syiar from the individual level (personal approach). The outreach activities in East Lampung Regency are in form of oral preaching (bi allisan) and deed preaching (bi alhaal). These methods should be applied in wise and good advice (bilhikmah wal mauizhatul hasanah). These models of Islamic syiar are relevant to the conditions of East Lampung's people, which are heterogeneous and multi-ethnic.

\section{Socio-Cultural Approach}

This kind of approach uses social and cultural methods that are developed in the society. This is necessary to know Muslims' tendency in Indonesia, especially those in East Lampung regency, who are very strong in holding their traditional rites their daily life. In this case, no society can be separated from the socio-cultural ties in everyday lives. Every movement and behavior of the people is always assessed based on the prevailing social and cultural system. Thus, to touch the life joints of the community, it necessary for religious counselors to consider the socio-cultural based approach. This approach will not make the Islamic syiar preached by religious counselors as an elitist and there is no a space between them and the people's life and traditions. However, the process of integrating religious messages and people traditions is not an easy way. Religious counselors should carry out the mission and enlighten Muslims with the divine revelation without encountering the people tradition destructively. Yet, their attitudes, actions, and behavior remain grounded and synergized with with the inhabitants of the earth (the interview with participant 1, a functional religion counselors in Batanghari District, February 15, 2020).

The socio-cultural Islamic syiar approach requires patience. Religious counselors need to listen more than to speak. They must develop a flexibility openness atmosphere when they are in the society. This is important to do in order to trigger the public acceptance of religious counselors. The exposure shown by the religious counselors is to build people's trust to them. Therefore, it will be easier to find solutions to solve the existing problems among them. Even if the religious counselors are speaking, their speech brings out a solution. For them, it is more important to have an ability to listen than to speak. The 
capability to listen is essential as they can diagnose quickly the people problems and provide them appropriate solutions. Although some of people attitudes are deviate from Islamic teaching, the religious counselors should respect every culture and habit that exists in the community while giving them religious guidance and direction without condemn them.

They have to show the path of kindness with empathy and sympathy. Even though these religious counselors have a deep knowledge of the religion, they do not need to patronize. They should always build a festive atmosphere. To identify the solution in solving the people problem, the religious counselors has to discuss with potential people in the community about the problem they are facing. If there is a disputable opinion among the people in solving the problem, the religious counselors need to act neutrally and facilitate wisely communication among them. So that, there is a common ground in resolving differences and conflicts that occur (the interview with participant 2, a functional religion counselors in Pekalongan District, February 10, 2020).

The socio-cultural Islamic syiar approach carried out by the religious counselors is relevant to be applied in the village community. Village communities are those who hold thickly various cultures and diverse traditions. Religious counselors need to understand the cultural peculiarities of each village. They can access the culture of the village community through the prefostered majelis taklim and praying congragations. From the existing majelis taklim, religious counselors will understand more detail each culture and tradition in the village. After knowing the village community's rules and culture, the religious counselors starts to socialize the religious values to the target communities. Furthermore, the religious counselors interact with the wider village community using natural process without rushing to do Islamic syiar activities (the interview with Participant 10, religious leader of Pekalongan District, East Lampung Regency, March 9, 2020).

\section{Psychological Approach}

The increasing of the complex life of the modern society rises various psychological problems. This is due to an increase in tension to fulfill all life style wishes and uncertain conditions. This condition also causes many people to suffer from various diseases, beginning from minor illnesses to severe illnesses, not only physical illness but also mental illness. Both often trigger an extensive disease. The Islamic syiar approach to people who are in a psychologically unstable condition needs to be done in a specific way. A 
hazardous mental disorder can cause a Muslim to do things that are not following Islamic teachings. Because you want to get well soon, you take a shortcut to come to psychics to get a support and to ask for treatment, and so on (The interview with Participant 8, Head of the East Lampung Islamic Guidance Section, February 10, 2020).

The Islamic syiar activities with a psychological approach can be carried out by religious counselors in hospitals or local community health centers (Puskesmas). the hospital is a priority place for counseling because there are so many patients who need mental treatment go there. The number of people who suffer from the disease is increasing from year to year. These people can be the target of the religious counselors' Islamic syiar by giving them motivation to still practice Islamic teaching or pray in all conditions. The hospital employees also need religious counseling considering that they mingle with patients every day. The service system in treating patients also needs religious values that hospital employees need to possess (the interview with Participant 3, functional religion instructor in Batanghari Nuban District, February 15, 2020).

Apart from hospitals, the psychological Islamic syiar approach can also be made in prisons. There is one Correctional Institution (LAPAS) in East Lampung, namely Class II-B Prison in Sukadana City. Religious counselors deliver Islamic syiar in this correctional institution to the employees/officers and prisoners. Counseling employees/officers is essential, considering that they have daily contact with prisoners. Apart from employees, the target of Islamic syiar is also prisoners. With religious counseling, they are expected to be more aware that their duties are to do religious teachings and to practice religious responsibilities. The way the religious counselors have to do to prisoners is to give them motivation and to encourage them to cultivate spiritual awareness to correct their mistakes. Inviting them to return to the right path by giving them enlightenment that Allah SWT will accept his repentance is also a kind of psychological aspect of Islamic syiar. The repentance will open a new leaf for the rest of their lives both in the jail and when they are free (the interview with participant 3, honorary Islamic extension agent, Batanghari participant 3 District, January 7, 2020).

Every person tends to know things that are invisible. For example, I want to know about death, the soul life in other dimensions. Religious counselors can do this with a psychological approach. Humans believe in different size of the life they lead daily. This encourages humans to make an effort to find out about this. A psychological system is essential for religious counselors because 
psychology and religion are so close and even influences one another. Humans can be touched by their hearts from spiritual influences that come from outside them. Therefore, it is easier for religious counselors who master this approach to conduct religious education to the community. (the interview with Participant 12, Head of the Office of Religious Affairs, Batanghari District, East Lampung, February 10, 2020).

\section{Political Approach}

In a country system, decisions issued by the government are political decisions. In today's life of society, the political aspect is so dominant in influencing humans' life. It is essential for religious counselors as an extension of the government in religious aspect to carry out their duties professionally and responsibly. They should not be involved in political practices that cause them to stand with and support specific political parties, starting from the election of the head of village to the election of the president. A neutral political position of religious counselors can avoid them to catch in short-term political interests. On the other hand, religious counselors are obliged to bridge religious development interests to the government at any level, and whoever rules. They can cooperate and synergize their program with other government institutions, so that they have a real contribution in solving the existing national problems. Therefore, there is no longer an assumption stating that religious counselors do not touch social issues because they work alone and without a clear focus and without a synergy with other government institutions. (the interview with Habiburrahman, religious counselor of Metro Kibang District, February 8, 2020).

The religious counselors in East Lampung can work technically together with the National Narcotics Agency to prevent the drug abuse. They can work together with the National Population and Family Planning Board (BKKBN) to solve population problems. They can work together with the counselors of the Ministry of Agriculture to jointly solve agricultural and food security problems. They can synergize with the counselors of the Ministry of Fisheries and Marine Affairs to facilitate and empower communities in coastal areas. Likewise, they also can cooperate with the counselors of the Ministry of Health regarding awareness of healthy living in preventing disease, including preventing global pandemic outbreaks such as covid-19 or corona that has not ended yet. (Interview with Participant 3, Head of the Office of Religious Affairs, Batanghari Nuban District, February 15, 2020). 
The political Islamic syiar approach carried out by religious counselors can strengthen religious materials and society's perspectives on problems, whether it is about population, environment, agriculture, etc. They can feel religious nuances if they can do a synergy with other institution properly. It is no doubt that if the existing problems are approached with religious values correctly and adequately, it can be appropriately resolved. The relationship between the religious counselors and other government institutions is a complementary partner and each has the roles according to its field. This cooperation will strengthen the right points for both the religious counselors and other respective government institutions. The political Islamic syiar approach carried out by religious counselors can empower the target of Islamic syiar with programs funded by the government, private institutions, and related agencies. Religious extension is a systematic and planned effort to provide religious teaching and information on development through language and religious doors. These skills are needed by religious counselors to be successful in carrying out their duties, namely strengthening the quality of Muslims' diversity. (the interview with Participant 14, Head of the Ministry of Religion, East Lampung Regency, February 8, 2020).

The political Islamic syiar approach can be directed to empowering the goal of the community development process which one of them is the development of a democratic attitude. The program of religious counselors in developing democratic attitude is to provide a guidance and counseling to the community about freedom, a culture of respecting others' space, pluralism, tolerance, differences in choice in political activities organized by the government, anti-violence, etc. It is necessary to foster civil society, which is a crucial element in determining an effective democratic society. Thus, they have a relevance to the development of Muslims society in the real sense. They are starting from economic, cultural, political issues, mostly religious and educational issues. Input in development education concerns the needs and interests of the people. They consider that the target of development extension is the entire social, economic, and cultural system/ structure of the ummah and the framework of creating a system/ structure of society following Islamic teachings. In the future, religious counselors in East Lampung can play a significant role in developing all fields. Please have an exemplary dedication and work under their expertise. It has a noble goal to establish the people of East Lampung (the interview with Participant 13, Head of the Administrative Subdivision of the Ministry of Religion, East Lampung, March 13, 2020). 


\section{Strategy and Performance of Religious Counselors in Developing Religious Life}

Muslims carry out the Islamic syiar approach through socio-culture in Madura, East Java. As researched by Mohammad Hidayaturrahman on the integration of Tandhe' culture in Madura with Islamic teachings derived from the values of the Quran and the hadiths of the Prophet Muhammad SAW. Tandhe' is a dancing activity performed by men or women at a wedding ceremony. The time for Tandhe' is accompanied by traditional Madurese music with saronen. After a Tandhe dancer "is in the middle of the audience or the invitees are present, the adult men who are present usually join the dance with the Tandhe player. "When the adult men dance with the Tandhe players', their position is very close and often physically touching, holding hands. Simultaneously, other adult males usually participate in the arena by giving money to the Tandhe players. And so on, the adult men took turns dancing with the Tandhe players' in the middle of a wedding party.

The tradition is more and more enduring because there are groups of Tandhe' enthusiasts who are usually invited to every wedding event to enliven the bride and groom's family wedding celebration. In Madura, the sociocultural model of Islamic syiar approach to Tandhe' activities at weddings is to separate the marriage contract time from the Tandhe event. The religious leaders invited to marry off the bride, and the groom asked the family not to be made into one marriage contract and Tandhe'. The Tandhe' time, which usually lasts three and three nights, was further reduced, being only about half a day in duration. According to religious leaders in Madura, people's cultural behavior can only be approached by culture as well (Hidayaturrahman, 2018).

The socio-cultural approach carried out by the religious counselors in East Lampung is carried out in a more straightforward form. They approach people socio-culture through the majelis taklim assembly. In which they could access people's socio-cultural life in the village. The Islamic syiar process through socio-cultural approach carried out by the religious counselors in East Lampung is not quick and spontaneous, it needs and require socialization and acculturation. This is done to avoid clashes with existing community habits. What is also avoided is the friction between religious teaching and community leaders cultural beliefs who are already influencing the villagers' style of life. Misunderstanding with the village figures can be reduced by discussing all cultural problems in the pengajian without underestimating and damning the 
villagers' cultural beliefs. The friction conditions of the object of Islamic syiar disturb sometime the religious counselors' Islamic syiar activities.

On the other hand, the village community's condition, which is still paternalistic, can be used by religious counselors to approach influential figures in the village. Of course, religious counselors can access these figures through social and cultural approaches. What these figures like needs to be well understood by the religious counselors. By knowing the things the figures like, the communication will continue well. Henceforth, the interaction process will run smoothly. From this condition, Religious counselors will establish the interaction of religious extension agents with a broader layer of village society. Siti Marwiyah and friends photograph how paternalism in the village can shape village communities' behavior and habits in their daily lives, including in activities and relationships with the government at the village level. (Marwiyah et al., 2020). Sumartono investigated the condition of the village community, which was still paternalistic. In one hand, paternalism causes villagers to remain dependent on elite figures in the village. This can lead to positive things if following the figures leads to positive things or activities (Sumartono, 2018).

The psychological Islamic syiar approach is suitable to be applied by religious counselors who work in urban areas. People in the city who have a busy life and high work are vulnerable to suffer from psychological problems. So that, religious counselors who work in urban areas need to have their provisions in their psychology knowledge. With this capital, it will be easier for them to carry out Islamic syiar. Religious counselors in East Lampung target urban communities in various locations that can be reached in carrying out Islamic syiar activities. Namely, among other things, the housing complex for private employees, the State Civil Apparatus (ASN), and entrepreneurs. Likewise, the hospitals and the community health centers (Puskesmas) are the targets of religious counselors activities. Besides, offices and factories are located in the East Lampung region. Correctional institution is also the main target of Islamic syiar. Interaction with groups and objects of Islamic syiar requires psychological abilities. Not just for religious knowledge, the religious counselors need an ability to understand their mental condition. As researched by the religious counselors in East Lampung, the psychological approach was also carried out by Apollo Harahap. Harahap examined the psychological process carried out to those who are involved in LGBT. A psychological approach is more appropriate for the LGBT group, considering it is a psychological distortion. So that the path to them is primarily a 
psychological approach (Harahap, 2016). The psychological approach to Islamic syiar is also carried out to traders. Traders are a group that is relatively well-established and economically independent. In groups which are economically stable and financially independent, they need a sense of security and comfort, and certainty about the future. During this situation, there are conditions of uncertainty regarding the business being run. Is the merchandise in demand or not. Will you be lucky today, or will you even lose? For the merchant group, a psychological Islamic syiar approach was also carried out. Such as research conducted by Muhammad Agung and Jhon Herwanto. Agung and Herwanto researched traders in Pekanbaru, Riau (Agung \& Herwanto, 2017).

The political approach in Islamic syiar is an option that religious educators need to consider. Given the political aspects of the present era in Indonesia are essential. Everything related to the public interest is related to politics. Political power rests in the hands of the ruling party as well as the verdict government institutions. The Religious counselors need to synergize the potential and opportunities with other government institutions which have fellow counselors. For example, The Religious counselors synergize with counselors in agriculture, health, village, and others. Likewise, existing programs at the district level are synergized by religious counselors in the context of community empowerment.

When related counselors' empowerment activities occur, the religious counselors enters the mental, spiritual development of the object of Islamic syiar. This political Islamic syiar approach model also accelerates the Islamic syiar process in the field. There are parts of the Islamic syiar target that cannot be targeted, with a political approach that can be reached. The preaching of a political approach was also studied by Muhammad Makmun Rasyid, who examined the process of Islamic syiar rahmatan Lil 'Alamin, including the political preaching carried out by KH. Hasyim Muzadi. Rasyid argued, with preaching that touched political aspects, Hasyim Muzadi presented Islam as a blessing for all nature and Islam is holistic, comprehensive an non partial. Islam, including political life, colors all aspects of the life of the ummah. This is one of the advantages of Hasyim Muzadi as an Islamic figure who can knit existing strengths into forces that create peace. (Rasyid, 2016). 
Efa Rubawati also researched political approaches. Rubawati revealed that various methods were needed in conducting Islamic syiar. Moreover, the preaching carried out in the new media era must be more adaptive and transformative (Rubawati, 2018). The Religious counselors need to be careful in their approach to politics. Do not get involved in practical political activities at all levels, including the village, regional, provincial, and national levels. Because once they are involved in practical political activities, squares and strongholds in the community will be formed and this is not conducive to Islamic syiar activities in the future.

Figure 1. Approach Model of Religious Counselors Islamic syiar in East Lampung (Mubasit \& Yanti, 2020).

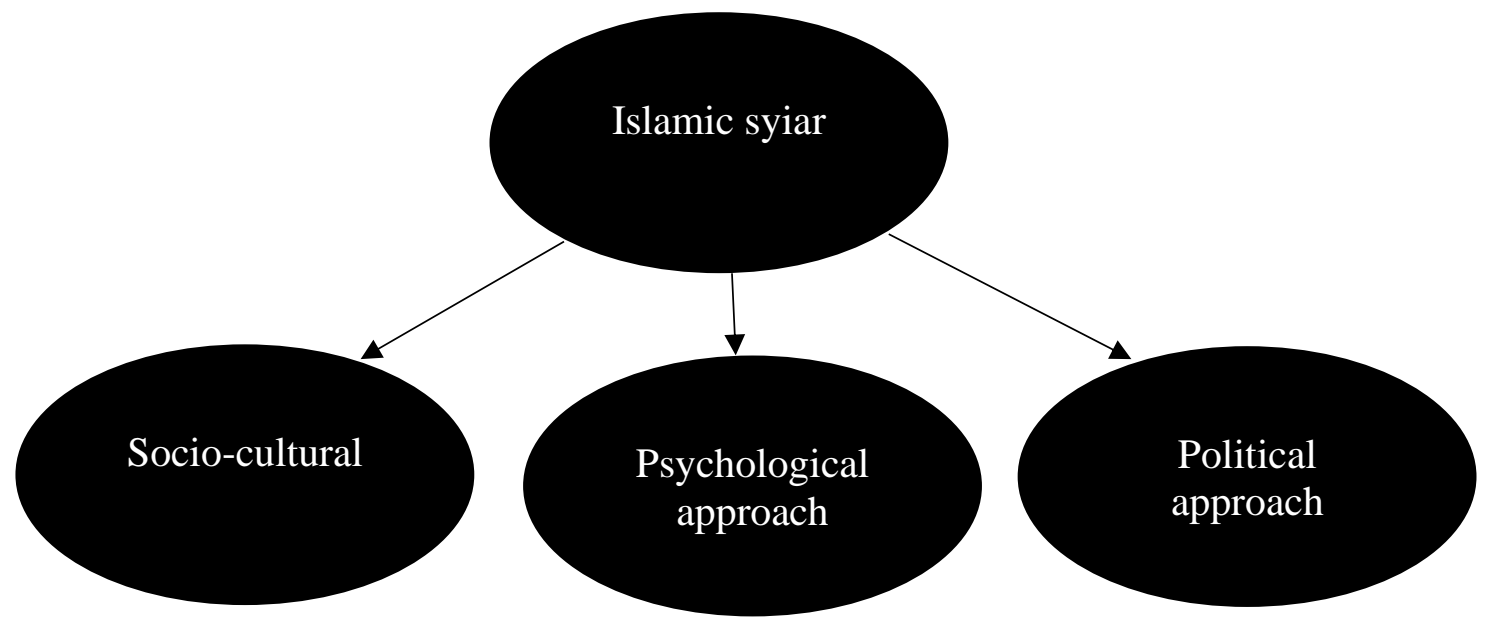

\section{Conclusion}

The Islamic syiar approaches carried out by religious counselors is not singular. This is related to the heterogeneous and plural conditions of the people of East Lampung. The Islamic syiar approach needs to be applied in several models. Based on the conducted research, there are at least three Islamic syiar models that have been implemented. Socio-cultural approach model. This model is mostly carried out to Islamic syiar objects in rural areas. Another model is the psychological approach. This model is carried out in preaching Islam in urban areas, such as in offices, housing complex, hospitals, and prisons. The last model is the political approach.

This approach is carried out to those who are considered difficult to be approached culturally or psychologically. It needs a power approach through government programs. This is done to elite groups and figures in society. The whole Islamic syiar approach requires the ability and multi-skill of religious 
counselors. For who do not have psychological skills cannot preach well to urban groups in housing and offices. So that mapping the location of assignments for religious counselors needs the attention from the Ministry of Religious affair. When they were educated and upgraded their abilities, the things mentioned before need to be taken into consideration. This means that they are not generalized as a whole.

\section{Referensi}

Abazari, Z., \& Borjian Brojeni, M. (2017). The role of Harold Lasswell Communication Theory in Librarianship and Information Science. International Academic Journal of Humanities, 4(1), 187-199. www.iaiest.com

Afianto, I. D., \& Utami, H. N. (2017). Pengaruh disiplin kerja dan komunikasi organisasi terhadap kepuasan kerja dan kinerja karyawan (studi pada karyawan divisi marketing pt. victory international futures kota malang). Jurnal Administrasi Bisnis, 5o(6), 58-67.

Agung, I. M., \& Herwanto, J. (2017). Pedagang yang Amanah: Studi Eksplorasi Dengan Pendekatan Psikologi Indigenous. Psympathic: Jurnal Ilmiah Psikologi, 4(1), 133140. https://doi.org/10.15575/psy.v4i1.1259

Ali, N., \& Noor, S. (2019). Pendidikan Islam Multikultur: Relevansi, Tantangan, dan Peluang. Jurnal Hadratul Madaniyah, 6(1), 24-42. https://doi.org/10.33084/jhm.v6i1.879

Amanda, M. O., Salam, R., \& Saggaf, S. (2016). Pengaruh Supervisi Kepala Sekolah Terhadap Kinerja Guru Di SMK Negeri 1 Bungoro Kabupaten Pangkep. Prosiding Seminar Nasional Himpunan Sarjana Ilmu-Ilmu Sosial, 2, 149-154.

Andayani, I., \& Tirtayasa, S. (2019). Pengaruh Kepemimpinan dan Budaya Organisasi Terhadap Kinerja Pegawai. Maneggio: Jurnal Ilmiah Magister Manajemen, 2(1), 4554. https://doi.org/10.29259/jmbs.v16i3.7381

Andrian, B. (2019). Pola Komunikasi Penyuluh Agama Islam Di Daerah 3T. Khazanah Sosial, 1(1), 32-48. https://doi.org/10.15575/ks.v1i1.7144

As'ad, A. (2018). Pengaruh Perencanaan Kerja dan Komunikasi Terhadap Kinerja Karyawan. Paradoks Jurnal Ilmu Ekonomi, 1(1), 165-182.

Bahtiar, A. T., Ghazali, B., Nasution, Y. Y., Shonhaji, S., \& Yanti, F. (2020). Islamic syiar Bil Hal: Empowering Muslim Economy in Garut. Ilmu Islamic syiar: Academic Journal for Homiletic Studies, 14(1), 125-144. https://doi.org/10.15575/idajhs.v14i1.9122

Bait, M. (2017). Penyuluhan Agama Berbasis Ekonomi Kepada Masyarakat Pasca Penutupan Lokalisasi Di Dusun Kalisari Banjarsari Trucuk Bojonegoro. At-Tuhfah Jurnal Keislaman, 6(1), 125-138.

https://doi.org/10.36840/jurnalstudikeislaman.v6i1.143 
Barmawie, B., \& Humaira, F. (2018). Strategi komunikasi penyuluh agama islam dalam membina toleransi umat beragama. ORASI: Jurnal Islamic syiar Dan Komunikasi, 9(2), 1-14. https://doi.org/10.32795/ds.v9i2.143

Budiantoro, W. (2018). Islamic syiar di Era Digital. KOMUNIKA: Jurnal Islamic syiar Dan Komunikasi, 11(2), 263-281. https://doi.org/10.24090/komunika.v11i2.1369

Busyro, Ananda, A. H., \& Tarihoran, A. S. (2019). Moderasi islam (wasathiyyah) di tengah pluralisme agama indonesia. FUADUNA: Jurnal Kajian Kegamaan Dan Kemasyarakatan, 03(01), 1-12.

Dachlan, M. (2017). Membangun Harmoni Melalui Penyuluhan Agama. Jurnal Mimikri, 3(1), 101-113.

Fachrezi, H., \& Khair, H. (2020). Pengaruh Komunikasi, Motivasi dan Lingkungan Kerja Terhadap Kinerja Karyawan Pada PT. Angkasa Pura II (Persero) Kantor Cabang Kualanamu. Maneggio: Jurnal Ilmiah Magister Manajemen, 3(1), 107-119. https://doi.org/10.30596/maneggio.v3i1.4834

Fibriyani, V., \& Mufidah, E. (2018). Pengaruh Faktor Eksternal Dan Internal Terhadap Kinerja Umkm Di Kota Pasuruan. Conference on Innovation and Application of Science and Technology, 148-157. https://doi.org/10.30736/jpensi.v3i3.190

Fitria, R., \& Aditia, R. (2019). Prospek dan Tantangan Islamic syiar Bil Qalam sebagai Metode Komunikasi Islamic syiar. Jurnal Ilmiah Syi'ar, 19(2), 224. https://doi.org/10.29300/syr.v19i2.2551

Hakim, R. (2017). Islamic syiar Bil Hal: Implementasi Nilai Amanah dalam Organisasi Pengelola Zakat untuk Mengurangi Kesenjangan dan Kemiskinan. IQTISHODIA: Jurnal Ekonomi Syariah, 02(02), 42-63.

Harahap, R. D. K. A. (2016). LGBT di Indonesia: Perspektif Hukum Islam, HAM, Psikologi dan Pendekatan Mașlahah. Al-Ahkam, 26(2), 223-248.

Hidayat, N. L. (2020). Strategi Komunikasi Islamic syiar Penyuluh Agama Islam Dalam Pembinaan Keluarga Sakinah (Studi Kasus Di Kampung Sakinah Kabupaten Jember). Indonesian Journal of Islamic Communication, 3(1), 40-66.

Hidayaturrahman, M. (2017). Corporate social responsibility strategi komunikasi perusahaan migas. Jurnal Nomosleca, 3(2), 614-624. https://doi.org/https://doi.org/10.26905/nomosleca.v3i2.2036

Hidayaturrahman, M. (2018). Integration of Islam and Local Culture: Tandhe' in Madura. Miqot, XIII(1), 189-206.

Ilham. (2018). Peranan Penyuluh Agama Islam dalam Islamic syiar Ilham UIN Antasari Banjarmasin. Jurnal Alhadharah Ilmu Islamic syiar, 17(33), 49-80.

Indriani, S. A. (2019). Kontribusi Penyuluh Agama Islam Sebagai Pendidik Non Formal Dalam Menambah Wawasan Keberagamaan Pada Masyarakat. HISBAH: Jurnal Bimbingan Konseling Dan Islamic syiar Islam, 16(2), 196-205.

Iskandar, I. (2018). Islamic Economics as A New Current of Economic Development in Indonesia. Muqtasid: Jurnal Ekonomi Dan Perbankan Syariah, 9(2), 150. https://doi.org/10.18326/muqtasid.v9i2.150-158 
Isnanto, S. H. (2018). Berbagai Masalah Dan Tantangan Radikalisasi Dan Deradikalisasi Terorisme Di Indonesia. Jurnal Pertahanan \& Bela Negara, 5(2), 225-244. https://doi.org/10.33172/jpbh.v5i2.366

Jaya, P. H. I. (2017). Revitalisasi Peran Penyuluh Agama Dalam Fungsinya Sebagai Konselor Dan Pendamping Masyarakat. Jurnal Bimbingan Konseling Islam, 8(2), 335-356.

Kamaluddin. (2020). Bentuk-Bentuk Komunikasi dalam Perspektif Islamic syiar Islam. Tadbir Jurnal Manajemen Islamic syiar, 2(2), 255-268.

Keyton, J. (2017). Communication in Organizations. Annual Review of Organizational Psychology and Organizational Behavior, 4, 501-526.

https://doi.org/10.1146/annurev-orgpsych-032516-113341

Kholili, K. (2017). Restrukturisasi Organisasi Islamic syiar Yang Komprehensip [Kajian Terhadap Upaya Penjabaran Islamic syiar Berdasarkan Pmano. 13 Tahun 2012]. Tasamuh, 15(1), 49-62. https://doi.org/10.20414/tasamuh.v15i1.141

Kurniawan, D. (2018). Komunikasi Model Laswell Dan Stimulus-Organism-Response Dalam Mewujudkan Pembelajaran Menyenangkan. Jurnal Komunikasi Pendidikan, 2(1), 6o. https://doi.org/10.32585/jkp.v2i1.65

Kusnawan, A. (2017). Studi pemetaan Islamic syiar dalam penyuluhan agama. Jurnal Alhadharah Ilmu Islamic syiar, 16(31), 1-22.

Lasswell, H. D. (1979). The Signature of Power: Buildings, Communications, and Policy. In Routledge. Taylor \& Francis. d:/Downloads/MEMAHAMIILMUKOMUNIKASI.pdf

Lawasi, E. S., \& Triatmanto, B. (2017). Pengaruh Komunikasi, Motivasi, Dan Kerjasama Tim Terhadap Peningkatan Kinerja Karyawan. Jurnal Manajemen Dan Kewirausahaan, 5(1), 47-57. https://doi.org/10.26905/jmdk.v5i1.1313

Manu, N. L., Subekti, A., \& Alfa, F. (2020). Peranan penyuluh agama dalam memberikan bimbingan terhadap calon mempelai di kantor urusan agama (kua) kecamatan klojen kota malang. Hikmatina: Jurnal Ilmiah Hukum Keluarga Islam, 2(2017), 1-7.

Marfu'ah, U. (2018). Strategi Komunikasi Islamic syiar Berbasis Multikultural. Islamic Communication Journal, 2(2), 147. https://doi.org/10.21580/icj.2017.2.2.2166

Margaretha, F., \& Letty. (2017). Faktor-Faktor Yang Memengaruhi Kinerja Keuangan Perbankan Indonesia. Manajemen Keuangan, 6(2), 84-96.

Marta, Rizo García. (2006). George Simmel, Sociabilidad e Interacción: aportes a la ciencia de la comunicación. Cinta de Moebio, 27, 266-283.

Marwiyah, S., Halima, N., \& Maulidi, F. (2020). Analisis Tipe Kepemimpinan Paternalistik Dalam Peningkatan Pelayanan Publik di Tengah Situasi Pandemik Covid-19. Jurnal Inovasi Ilmu Sosial Dan Politik, 2(2), 137-145. https://doi.org/10.33474/jisop.v2i2.6689

Masrial. (2018). Islamic syiar dan Pemberdayaan Masyarakat. Turast: Jurnal Penelitian Dan Pengabdian, 6(1), 67-78. https://doi.org/10.29300/syr.v18i2.1676 
Mele, V. (2017). Social Interaction. In Bryan S. Turner (Ed.), The Wiley-Blackwell Encyclopedia of Social Theory (pp. 1-4). John Wiley \& Sons, Ltd. Published. https://doi.org/10.1002/9781118430873.est0811

Miles; , M. B., \& Huberman, A. M. (1994). Qualitative Data Analysis: An Expanded Sourcebook. In R. Holland (Ed.), Sage (2nd ed.). SAGE Publications, Inc.

Muchlis, S. (2020). WhatsApp as a Da'wah Media for Islamic Religious Councelor during Covid-19 Pandemic. Jurnal Simbolika: Research and Learning in Communication Study, 6(2), 134-142.

Mujahidin, A. (2008). pengentasan kemiskinan dalam prespektif ekonomi islam. AlFikra: Jurnal Ilmiah Keislaman, 7(1), 168-185.

Munawar, H. (2017). Pengaruh Pelaksanaan Kebijakan Pengembangan Agama Islam terhadap Koordinasi Penyuluh dengan Pengawas Pendidikan Agama Islam untuk Mewujudkan Efektivitas Program Pendidikan Agama Islam. Jurnal Pendidikan UNIGA, 11(1), 18-25. http://journal.uniga.ac.id/index.php/JP/article/view/25

Muslihudin, M., Kurniawan, D., \& Widyaningrum, I. (2017). Implementasi Model Fuzzy SAW Dalam Penilaian Kinerja Penyuluh Agama. Jurnal TAM (Technology Acceptance Model )), 8(1), 39-44.

Ningrum, M. E. (2013). Peranan Komunikasi Internal Di Lingkungan Kerja. Indept, 3(1), 25-30.

Nurhayati, H., Kusnawan, A., \& Nuraeni, H. G. (2018). Metode Tabligh Ustadz Yopi Nurdiansyah. Tabligh: Jurnal Komunikasi Dan Penyiaran Islam, 3(4), 428-444. https://doi.org/10.15575/tabligh.v3i4.737

Nurnaningsih, S., \& Wahyono. (2017). Pengaruh Kepuasan Kerja, Motivasi Kerja Dan Komitmen Organisasi Terhadap Kinerja Melalui Organizational Citizenship Behavior (Ocb) Sebagai Variabel Intervening. Economic Education Analysis Journal, 6(2), 365-378.

Ramdhani, R. (2018). Islamic syiar dan Pemberdayaan Masyarakat Berbasis Agama. Jurnal Syi'ar, 18(2), 8-25.

Rasyid, M. M. (2016). Islam Rahmatan Lil Alamin Perspektif Kh. Hasyim Muzadi. Epistemé: Jurnal Pengembangan Ilmu Keislaman, 11(1), 93-116. https://doi.org/10.21274/epis.2016.11.1.93-116

Rialmi, Z., \& Morsen, M. (2020). Pengaruh Komunikasi Terhadap Kinerja Karyawan PT Utama Metal Abadi. JENIUS (Jurnal Ilmiah Manajemen Sumber Daya Manusia), 3(2), 221-228. https://doi.org/10.32493/jjsdm.v3i2.3940

Roessler, B., \& Mokrosinska, D. (2013). Privacy and social interaction. Philosophy and Social Criticism, 39(8), 771-791. https://doi.org/10.1177/0191453713494968

Rosidin, R., Widodo, W., \& Aminah, S. (2020). Strategi Penyuluh Agama Dalam Pemberdayaan Muallaf Turi Kabupaten Sleman. Al Qalam: Jurnal Ilmiah Keagamaan Dan Kemasyarakatan, 14(1), 1. https://doi.org/10.35931/aq.v14i1.204

Rubawati, E. (2018). Media Baru: Tantangan dan Peluang Islamic syiar. Jurnal Studi Komunikasi, 2(1), 126-142. https://doi.org/10.25139/jsk.v2i1.510 
Rustandi, R. (2020). CyberIslamic syiar: Internet Sebagai Media Baru Dalam Sistem Komunikasi Islamic syiar Islam. NALAR: Jurnal Peradaban Dan Pemikiran Islam, 3(2), 84-95. https://doi.org/10.23971/njppi.v3i2.1678

Sumartono, S. (2018). Budaya Politik Dalam Masyarakat Pragmatis. LUGAS Jurnal Komunikasi, 2(1), 20-26. https://doi.org/10.31334/jl.v2i1.119

Surahmat. (2020). The role of functional islam religion counsellor in marriage consultation in sleman regency (a review on islamic counselling). Jurnal Komunikasi Dan Pendidikan Islam, 9(2), 220-253.

Suriani, J. (2018). Komunikasi Islamic syiar di era cyber. Jurnal An-Nida' Jurnal Pemikiran Islam, 42(2), 30-51.

Suriati. (2019). Islamic syiar dan terorisme. Jurnal Retorika, 1(1), 1-13.

Sutiyatno, S. (2018). The Effect of Teacher's Verbal Communication and Non-verbal Communication on Students' English Achievement. Journal of Language Teaching and Research, 9(2), 430. https://doi.org/10.17507/jltr.0902.28

Wahyuningsih, S. (2018). Pengaruh reputasi sebagai variabel intervening terhadap kinerja perusahaan pada pt.telkom kebumen. Jurnal Fokus Bisnis, 17(01), 41-53.

Wastiyah, L. J. (2020). Peran Manajemen Islamic syiar di Era Globalisasi (SebuahKekuatan, Kelemahan, Peluang dan Tantangan). Iradatuna Jurnal Kajian Manajemen Islamic syiar, 3(1), 1-16. https://doi.org/1010.24014/idarotuna.v3i1.Peran

Yulianingsih, L. T., \& Sobandi, A. (2017). Kinerja Mengajar Guru Sebagai Faktor Determinan Prestasi Belajar Siswa. Jurnal Pendidikan Manajemen Perkantoran, 2(2), 157-165. https://doi.org/10.17509/jpm.v2i2.8105

Yulianti, E. (2017). Komunikasi Dan Konflik Terhadap Kinerja Karyawan Melalui Komitmen Organisasi Sebagai Variabel Intervening. Journal of Business Studies, 2(2), 45-57.

Zaini, A. (2107). Islamic syiar dan pemberdayaan masyarakat perdesaan. Jurnal Ilmu Islamic syiar, 37(2), 284-301. 